\title{
Pattern of variation and grouping of qualitative morphological characters of bambara groundnut (Vigna subterranea (L.) Verdc.)
}

\author{
Nwakuche Chinenye ONWUBIKO ${ }^{1,2}$, Michael Ifeanyi UGURU ${ }^{3}$, Grace Ovute CHIMDI ${ }^{4}$
}

Pattern of variation and grouping of qualitative morphological characters of bambara groundnut (Vigna subterranea (L.) Verdc.)

Abstract: Morphological field evaluation to characterize the phenotypical features of 33 Bambara groundnut accessions was carried out at the Teaching and Research Farm of Department of Crop Science and Technology, Federal University of Technology, Owerri, Imo State; Nigeria. Qualitative morphological descriptors showed a varying degree of variation across the Bambara groundnut collections evaluated. In relation to other descriptors, ground colour of eye displayed the highest range of variation, while eye pattern of the accessions recorded the least discriminating feature. The accessions were resolved into five groups based on similarities on morphological characters and not on geographical place of origin.

Key words: Bambara groundnut; grouping; morphological variability; qualitative characters
Received September 27, 2019; accepted May 04, 2020.

Delo je prispelo 27. septembra 2019, sprejeto 04. maja 2020.

Vzorec spreminjanja in združevanja morfološki znakov bambare (Vigna subterranea (L.) Verdc.)

Izvleček: V raziskavi je bilo na terenu ovrednoteno 33 akcesij bambare (voandzeje) za opredelitev njihovih fenotipskih lastnosti na Teaching and Research Farm of Department of Crop Science and Technology, Federal University of Technology, Owerri, Imo State, Nigerija. Kakovostni morfološki deskriptorji so med akcesijami pokazali različno spremenljivost. Glede na ostale deskriptorje je osnovna barva hiluma pokazala največjo spremenljivost, medtem, ko je vzorec hiluma pakazal najmanjšo spremenljivost med akcesijami. Akcesije so se združevale v pet skupin na osnovi podobnosti v morfoloških lastnostih in ne na osnovi njihovega geografskega izvora.

Ključne besede: bambara; združevanje; mofološka variabilnost; kakovostni znaki

Federal University of Technology, Owerri, Department of Crop Science and Technology

2 Corresponding author, e-mail: nwakuche.onwubiko@futo.edu.ng

3 University of Nigeria, Nsukka, Department of Crop Science

4 Federal Polytechnic Bauchi, Department of Agricultural Technology 


\section{INTRODUCTION}

In conventional and modern breeding programme for crop improvement, the major factor that determines its success is the availability of variation within and between species (intra and interspecific variations). Natural variations exist in both wild and cultivated plants. Several scholars in their different studies have reported the importance of screening lines for the purpose of identification and classification of natural occurring variations in crop species (Ariyo and Odulaja, 1991; Aliero and Morakinyo, 2001; Ntundu et al., 2004; Santos et al., 2012; Afolayan et al., 2014).

In detection of variation, crop species are characterised in which the differences that exist in species are used to describe germplasm of crop species. Traditionally, standard characterization of accessions involves the use of descriptor list of morphological characters. In fact, most workers have solely relied on phenotypic morphological descriptors for the characterization of local varieties of crops (Caradus and Forde, 1996; El eSAWI, 2012), despite that the use of morphological descriptors presents some limitations. The environment sometimes influences the phenotype and there may be some ambiguity in information capture and interpretation. However, the use of other methods of diversity analysis (as it is currently being practiced) like biochemical, cytological, and molecular markers have not substituted phenotypic morphological characterization of collections (William et al.,1990; Afolayan et al., 2014), rather they play a complimentary role. This is because phenotypic morphological markers easily expose heritable characters to the eye in the natural crop environment and are highly discriminating. In addition, under a wide range of environmental conditions, some morphological characters are stable. Consequently, assessment and characterization of morphological characters is used for the identification of species, families and genera. It has been reported that studies in morphological characterization of plants have immensely enhanced derivation of economic and breeding gains from germplasm collections and families of related accessions (Iwaro et al., 2003; Bekele et al., 2006; Maharaj et al., 2011). Further, phenotypic morphological characterization of collections can provide reliable information on level of genetic diversity, structure and distribution of diversity.

Morphological characterization using qualitative characters typically involve the use of leaf, flower, fruit/ pod and seed descriptors (Engels et al., 1980; Bekele and Bekele 1996). In Bambara groundnut, the use of seed morphological features in the identification and classification of a wide range of germplasm has been reported (Mohammed, 2014), apparently demonstrating the use- fulness of morphological descriptors in the assessment of diversity that exit in Bambara groundnut. Also to maximise efforts made in the conservation of germplasm, identification of useful and valuable characters through morphological diversity analysis is essential. Therefore, this study was set up to identify and classify morphological variation that exist in Bambara groundnut with a view to establish the pattern of variation and to cluster the collections in groups.

\section{MATERIALS AND METHOD}

A total of 33 accessions of Bambara groundnut ( $\mathrm{Vi}$ gna subterranea (L.) Verdc.) obtained from the gene bank of International Institute of Tropical Agriculture (IITA) Ibadan was used for the study. These accessions were sourced from seven major African Bambara groundnut growing countries. Nigeria and Togo had twelve accessions each. Three accessions were from Malawi, while Mali and Cameroon had two accessions each. Ghana and Zambia had one accession each.

Field experiment was conducted in the late raining season of 2014, 2015 and 2016 at the Teaching and Research Farm of Department of Crop Science and Technology, Federal University of Technology, Owerri. The experimental design was randomized complete block design (RCBD) with 3 replications. A portion of land measuring $40 \mathrm{~m} \times 20 \mathrm{~m}$ was used. It was ploughed, harrowed and marked out into 3 blocks with a space of 1 meter between blocks. Two seeds were sown which was later thinned down to one. Planting spacing was maintained at $100 \mathrm{~cm}$ between rows and $20 \mathrm{~cm}$ within rows. Weeding, suppling and earthing up was carried out for optimum crop production. Data on morphological characters were collected as outlined in Bambara groundnut descriptor list developed by the International Bambara Groundnut Network (IPGRI, IITA, BAMNET, 2000).

Data collected from morphological qualitative characters were analysed visually and grouped based on colours, shapes, and texture using standard shape and colour charts of Royal Horticultural Society Colour Chart. In addition, statistical analysis to determine mean, and frequency distribution was carried out using GENSTAT 5.0 Release 4.23DE, Discovery Edition 3.

\section{RESULT AND DISCUSSION.}

The qualitative morphological traits used to characterize the Bambara groundnut accessions evaluated are shown in Tables 1 and 2. A varying degree of variation was revealed by these qualitative morphological 
descriptors across the collections. Most of the qualitative characters displayed broad variability among the accessions. Comparatively, ground colour of eye displayed the highest range of variation than other qualitative morphological characters. On the other hand, eye pattern of the accessions recorded the least distinguishable qualitative morphological variability. The details of the result on the qualitative descriptors used to discriminate among the accessions is discussed below.

Growth habit: The pattern of growth habit exhibited by the evaluated Bambara groundnut accessions (Table 1) were bunch (63.6\%), semi-bunch (18.2\%), and spreading $(18.2 \%)$. A detailed breakdown of this result showed that the predominant growth habit pattern among the accessions was bunch. A greater percentage (63.6) of the entire population had it. This result on growth habit may have some implication on evolution status of the crop. Doku and Karikari (1971) reported that Bambara groundnut grew from spreading growth habit to bunch. While bunch growth habit is characterized by short internode, spreading growth habit had long internode. The leaves of bunch growth habit were clustered, unlike the leaves of spreading growth habit. Literature report revealed that farmers prefer growing Bambara groundnut accessions with short internode length; they are easy to harvest than the long internode types. Again in selection, short internode types are considered as a desirable character for crop improvement (Goli et al.,1995; Doku, 1995). The internodes of the semi-bunch fall between that of bunch and spreading growth habit. They were moderately long. Apparently, the length of the internode determined the type of growth habit the accessions exhibited. This result is in agreement with the report of Goli et al. (1995).

Terminal leaflet shape: Four types of terminal leaflet shapes were observed among the accessions as shown in Table 3. They were lanceolate, oval, elliptic, and round. The distribution of the accessions among the observed four patterns of terminal leaflet shape were $30.3 \%$ for lanceolate, $39.4 \%$ oval, $39.4 \%$ elliptic and $6 \%$ round. This qualitative morphological character displayed a reasonable level of discrimination among the accessions. Again, a careful investigation on this result also showed that none of the observed four types of terminal leaflet shapes dominated the distribution. This result has some implication on evolution status of Bambara groundnut based on terminal leaflet shape. Further, the round type of terminal leaflet shape was not popular among the collections, only two accessions (or $6 \%$ ) of the collections had it. Apparently, this type of terminal leaflet is threatened to go into extinction, hence efforts should be made to salvage it. Again, terminal leaflets were observed to be slightly larger in size than the laterals leaflets. Terminal leaflets were subtended by two stipules while lateral leaflets were subtended by one. Similar reports on the arrangement of terminal leaflet of Bambara groundnut have been observed by other workers (Goli et al., 1995; Mohammed, 2014).

Eye (hilum) pattern: There were two types; eye as thin and no eye. Accessions that had eye as thin constituted $72.7 \%$ of the distribution, while $27.3 \%$ had eye pattern described as no eye (Table 1). The distribution was skewed towards eye pattern described as eye as thin. More than half of the accessions had this eye pattern. This qualitative character (eye pattern of the accessions) had the least variation in discriminating among the accessions. Invariably eye pattern of the accessions did not exhibit a reasonable distinguishable identity among the collections of Bambara groundnut evaluated. This result suggests the level of relatedness among these accessions, which is an expected natural occurrence. Again, it may imply that this crop is evolving from no eye type of eye pattern towards eye as thin.

Pod shape: Investigation on pod shape of the accessions showed that $69.7 \%$ of the accessions had pod shape described as ended in a point round on the other side, $15.2 \%$ had the type classified as ended without point, and $12.1 \%$ had pod shape that ended in a point with hook on the other side. Furthermore, $3 \%$ had pod shape described as ending in 2 points on each side (Table 1). Pod shape of the accessions like terminal leaflet shape was among the traits that displayed a reasonable variation among the collections evaluated. The pod shape that dominated the distribution was the type described as ended in a point, round on the other side. Over half $(69.7 \%)$ of the population had it. This result may have some evolutionary implication on the status of pod shape in Bambara groundnut. On the other hand, the pod shape classified as ending in 2 points on each side was seriously threatened to go into extinction, only $3 \%$ of the accession had it. Hence the need to commence breeding programme to salvage it.

Pod texture: The result on pod texture displayed by the accessions showed that $51.5 \%, 30.3 \%$, and $9.1 \%$ had much grove, little grove, and smooth pod texture in that order (Table 1). The variability displayed by the accessions on pod texture was comparatively narrow. Invariably this trait cannot be used in discriminating among the accessions. Hence, there is the need to use more descriptors in the characterization of the accessions to delimit them into distinct groups (Kok et al.,1989). However, the distribution was skewed towards much grove pod texture. Slightly above half ( $51.5 \%)$ of the accessions evaluated had this type of pod texture.

Pod colour: The frequency and percentage distribution of pod colour of the accessions (Table 1) showed that each of these two pod colours (purple and reddish) 
constituted $3 \%$ of the distribution. $12.1 \%$ of the accessions had pods that were black in colour, while $57.6 \%$ had brown coloured pods. The remaining $24.3 \%$ had yellowish-brown pods (Table 1). Pod colour displayed a reasonable level of discrimination among the accessions. The result on pod colour also showed that brown coloured pod was the most popular among the Bambara groundnut accessions evaluated, more than half (57.6 $\%)$ of the collections had it. This result is similar to that observed for much grove type of pod texture described above. Contrarily, the endangered pod colours were purple and reddish. Each of these pod colours constituted only $3 \%$ of the distribution. Hence the need to conserve them otherwise they may go into extinction. At harvest, the colour of the matured pod varies from yellow to reddish dark brown. This result is in agreement with the findings of Goli et al (1995). A detailed investigation on pod descriptors (pod shape, pod texture and pod colour) used to discriminate among the accessions showed that pod colour displayed the highest level of variability among the Bambara groundnut accessions. This result agrees with the report of a previous study on classification of Bambara groundnut morphotypes based on seed morphological features (Mohammed, 2014). In addition, previous studies have reported variations in seed and pod morphotypes as being very useful in discriminating among Bambara groundnut collections especially for genetic improvement programme (Padulosi et al., 2002; Mohammed, 2014).

Seed shape: $39.4 \%$ of the accessions had oval shaped seeds, $48.5 \%$ round seeds and $12.1 \%$ had seeds whose shape was described as others (Table 1). A further break down of this result showed that the level of discrimination of the accessions based on seed shape was relatively low, like the result on pod shape. Among the observed three types of seed shapes, none dominated the distribution, which is similar to the result on terminal leaflet shape. The result on seed shape of the accessions may have some implication on evolutionary status of the crop. However, there are several reports on the importance of seed characters of Bambara groundnut in the identification and classification of this crop (Massawe et al., 2005; Ntundu et al., 2006; Abu and Buah, 2011)

Ground colour of testa: Four types of ground colour of testa were observed among the collections evaluated as presented in Table 1. Cream colour constituted $39.4 \%$ of the distribution while $15.2 \%$ had dark brown colour. Furthermore, $33.3 \%$ had dark purple, and $9.1 \%$ light brownish red colour of testa. This qualitative morphological character displayed a reasonable level of variation among the accessions. Further, none of the observed four colours of the ground colour of testa of the accessions dominated the distribution which is similar to the results on terminal leaflet shape and seed shape.

Ground colour of eye (hilum): the result on ground colour of eye showed that brown circular and light brownish red were constituted by one accession (3\%) each. Similarly, $6.1 \%$ of the accessions had black triangular eye and brown triangular eye each. Grey triangular ground colour of eye constituted $9.1 \%$ of the distribution, while $18.2 \%$ of the accessions had grey butterfly-like eye. In addition, $54.5 \%$ had the type described as others (Table 1). Ground colour of eye described as others dominated the distribution, over half of the accessions had it. On the other hand, two types of ground colour of eye; brown circular and light brownish red have almost gone into extinction. Only $3 \%$ of the distribution had each of them. Urgent measures should be taken to salvage brown circular and light brownish red types of ground colour of eye. Comparatively, ground colour of eye displayed the highest range of variation than other traits amongst the Bambara groundnut accessions evaluated. This result offers opportunity for selection for crop improvement. It has been reported that selection is effective only when significant genetic variability exits in high frequency among the genotypes (Hahn,1997; Adebisi et al., 2001). Previous study on characterization of Bambara groundnut lines has reported a similar result (Mohammed, 2014).

Morphological traits cluster analysis or dendrogram of the 33 Bambara groundnut accession is displayed in Figure 1. Five main clusters were revealed by the dendrogram. The first group which also was the smallest had only one accession; TVSU 1688 from Togo. This accession had some outstanding morphological characters like high vigour index (9), smooth pod texture and yellowishbrown pod colour. The second group had two accessions; TVSU 1788 and TVSU 1638, and both were from Mali. Some common morphological or agronomic features of this group were two seeds per pod, bunch growth habit pattern, and earliness to number of days to $50 \%$ emergence ( 8 days). Group three clustered three accessions which comprised of TVSU 1713 from Zambia, TVSU 1605 from Togo, and TVSU 1510 from Nigeria. Accessions in this group were characterized mostly by earliness; 8 days to emergence and 37 days to flowering. In addition, many accessions in this group contained only one seed per pod. Another outstanding feature among accessions in this group was their growth habit pattern was mostly semi-spreading. The fourth and the largest group had fourteen accessions. Cameroon and Malawi had one accession each; TVSU 1819 and TVSU 1769 respectively. Togo had three accession; TVSU 1697, TVSU 1614 and TVSU 1702. The remaining nine accessions were from Nigeria; TVSU 1584, TVSU 1504, TVSU 1554, 


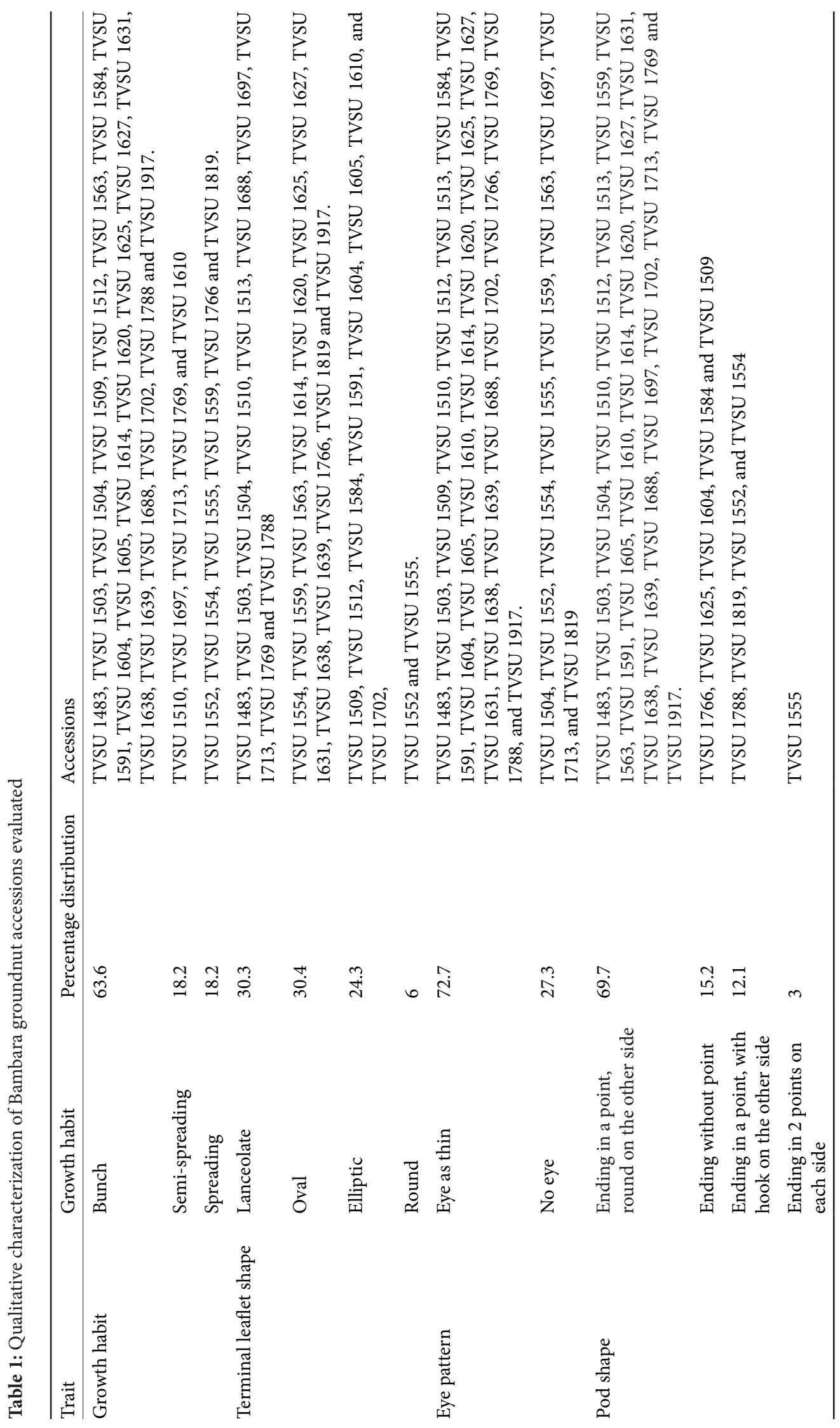




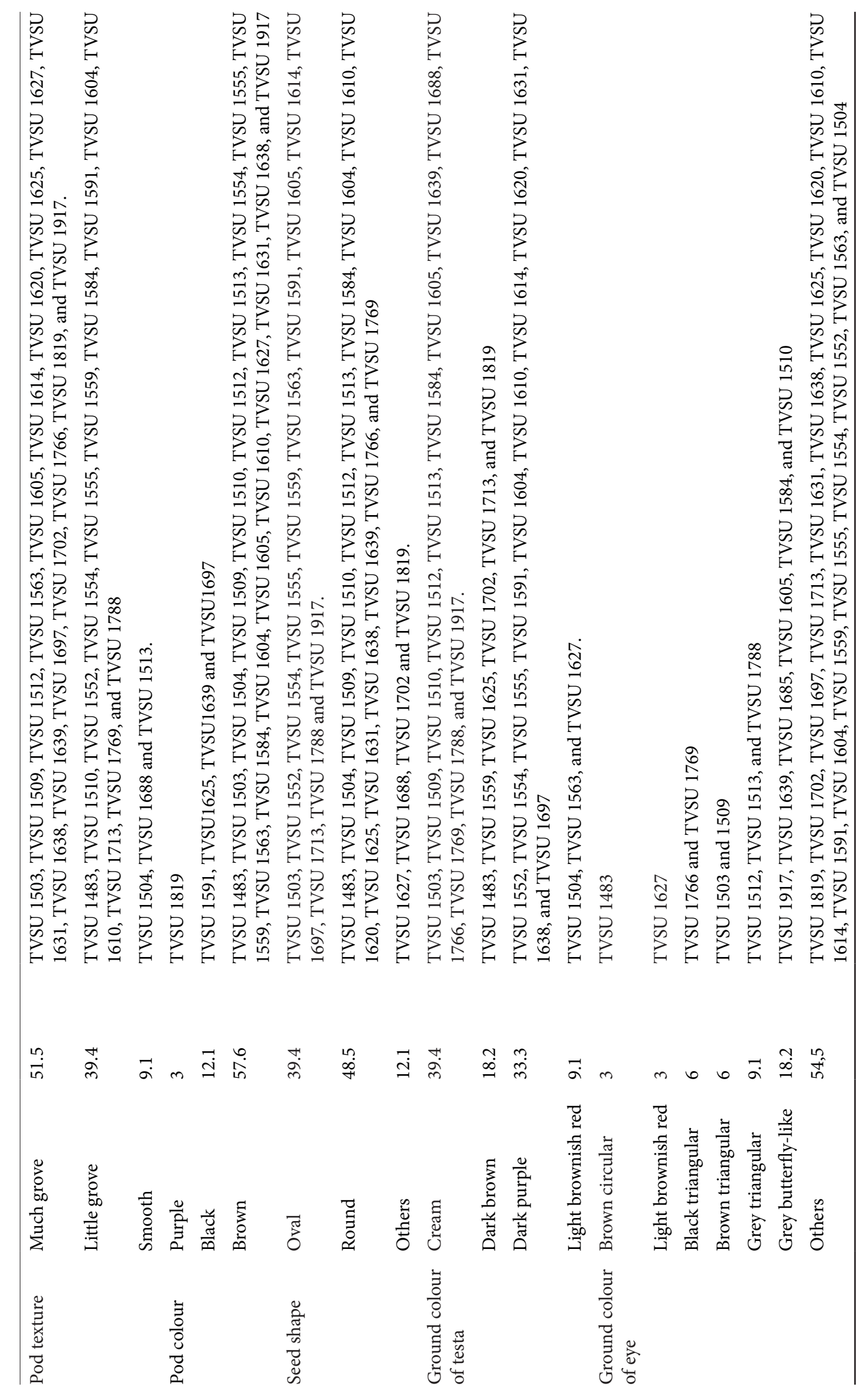




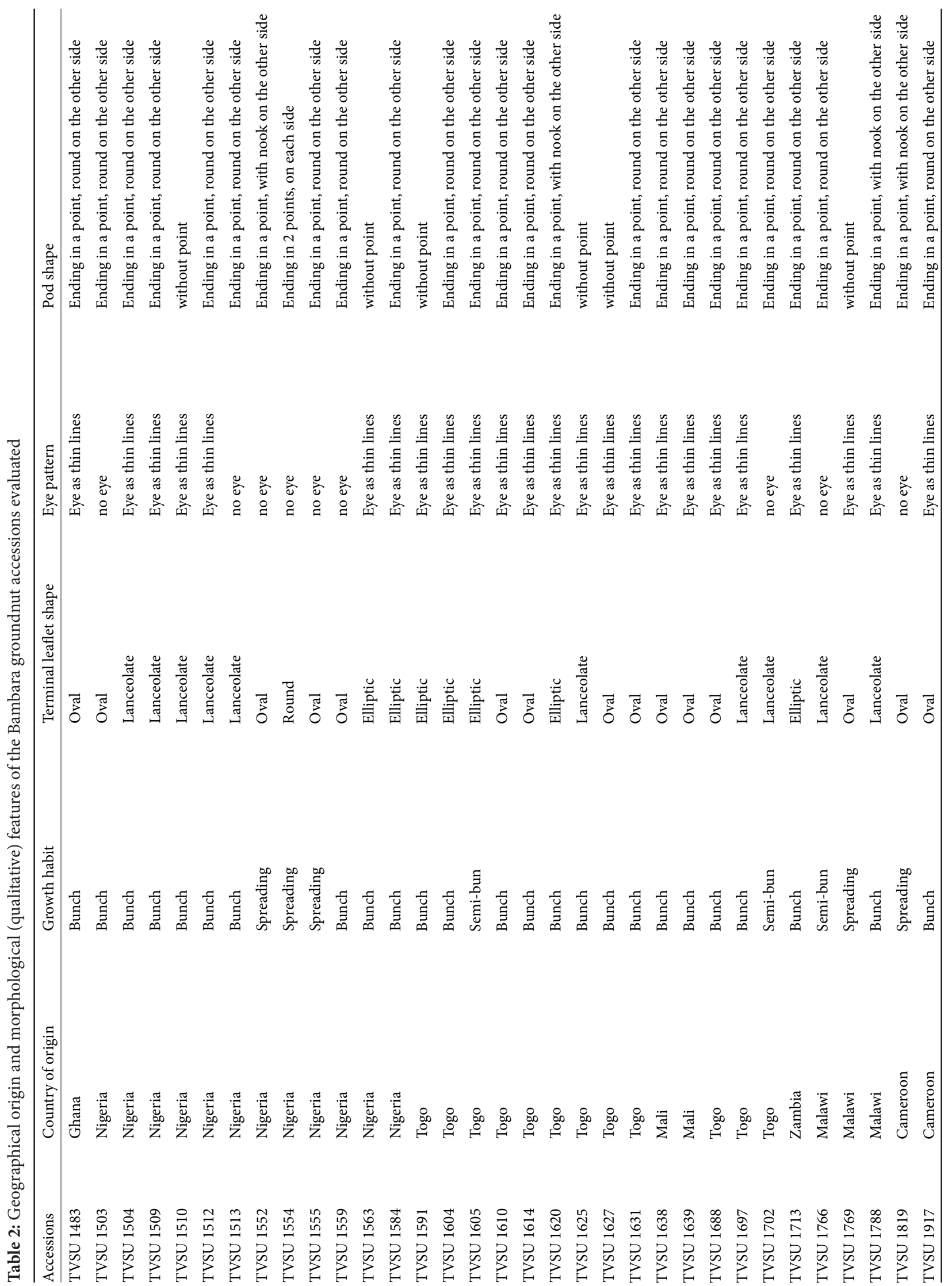




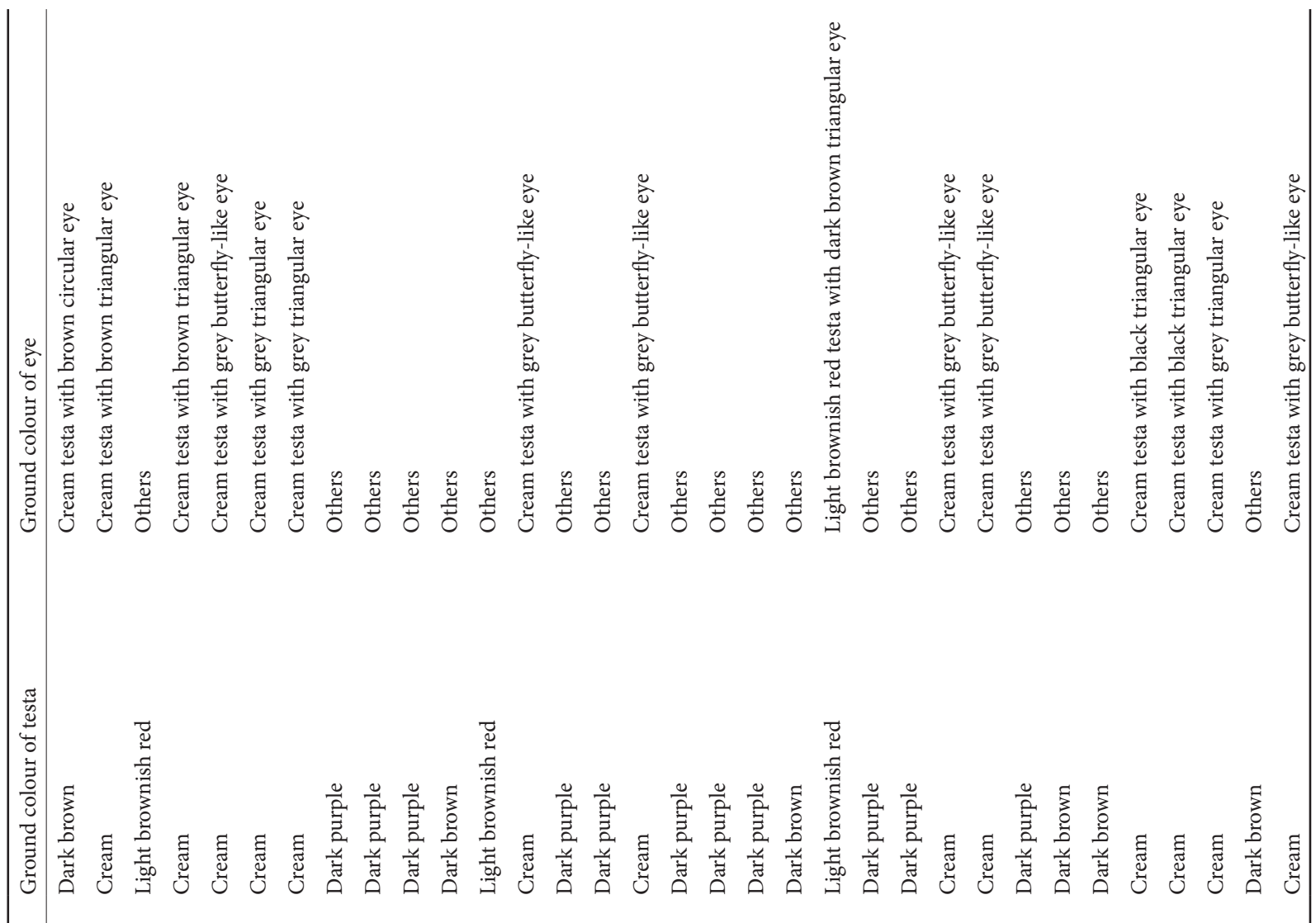

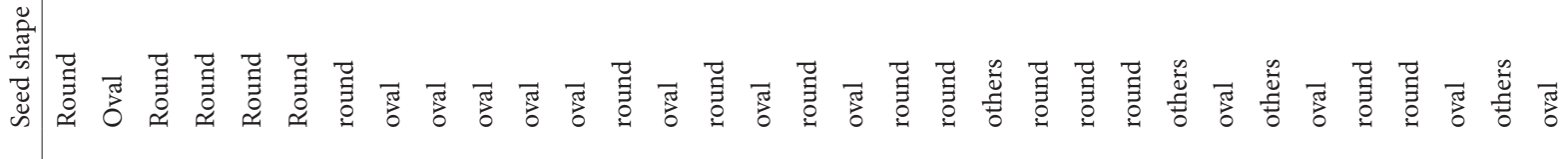

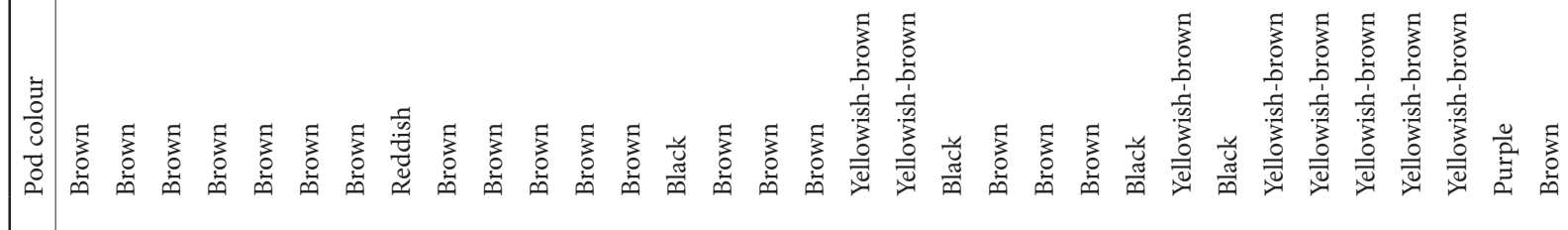

营

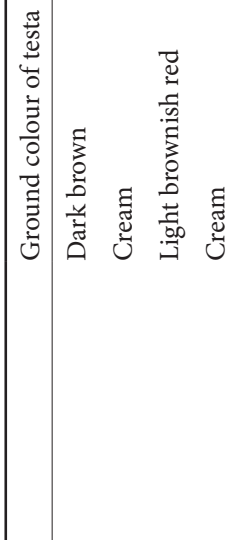

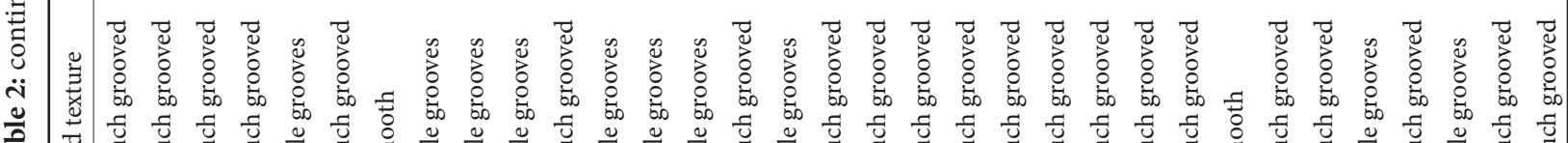

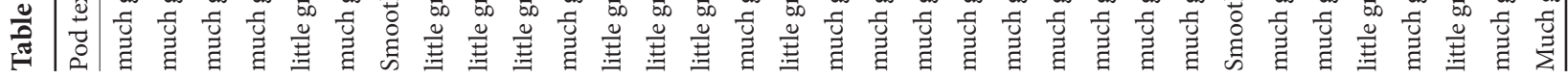


TVSU 1513, TVSU 1555, TVSU 1552, TVSU 1559, TVSU 1509 and TVSU 1503. The accessions in this cluster were similar in growth habit pattern (bunch), and their eye pattern was no eye. Again, majority of the accessions in this group had two seeds per pod. The fifth group was made up of the remaining thirteen accessions. They were mainly from Togo which had seven accessions; TVSU 1631 , TVSU 1610, TVSU 1627, TVSU 1604, TVSU 1620, TVSU 1591, and TVSU 1625. Other accessions in this group were two (TVSU 1563 and TVSU 1512) from Nigeria, and one accession each from Malawi (TVSU 1766), Mali (TVSU 1639), Cameroon (TVSU1917), and Ghana (TVSU 1483). These accessions had two common distinguishing agronomic features; their pod shape was mostly the type described as ending in a point, round on the other side and they had much grooved type of pod texture.

Summarily, the result on the grouping of the acces- sions did not cluster the evaluated Bambara groundnut accessions into groups based on geographical origin (place of collection), rather similarity on qualitative morphological features. Hence, this situation of mixture of geographically divergent Bambara groundnut accessions in the same cluster may have arisen due to the exchange of Bambara groundnut seeds between farmers over wide geographic-ethnic region. A similar trend of association between Bambara groundnut accessions from different geographical areas has been reported by a previous genetic diversity study, and it was concluded that these accessions may be related, similar or the same lines (Ntundu et al. 2006).

\section{CONCLUSION}

The qualitative morphological descriptors used in

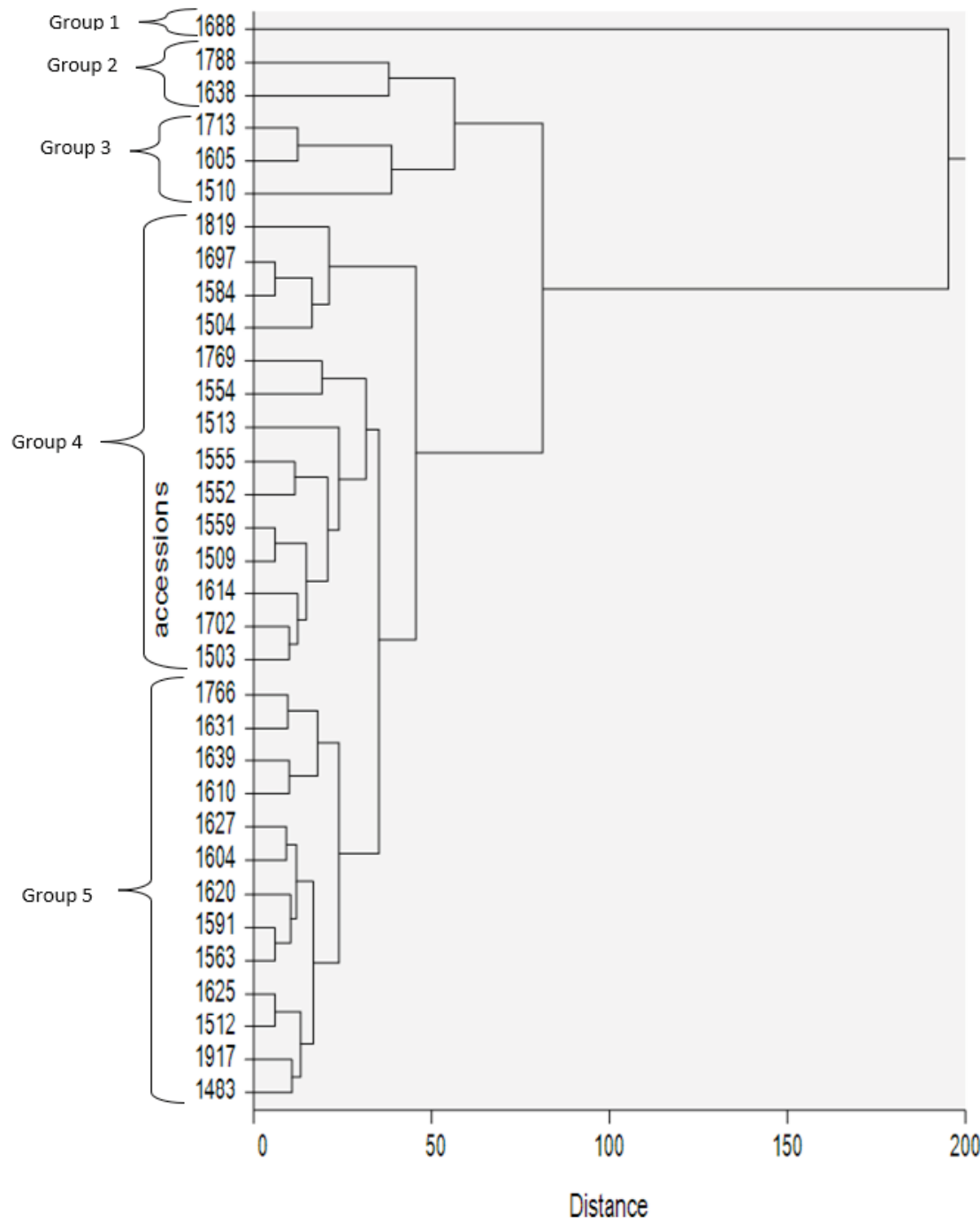

Figure 1: Dendrogram of 33 accessions of Bambara groundnut based on morphological characters 
this study had clearly shown varying levels of discrimination among the accessions of Bambara groundnut evaluated. At the extremes were ground colour of eye and eye pattern that had the highest and the least level of variation respectively. Other qualitative characters like leaflet shape, pod shape, ground colour of testa and pod colour showed reasonable range of variations among the collections. In addition, it was also observed that certain features in some qualitative traits like round type of terminal leaflet shape, brown circular and light brownish red types of ground colour of eye and pod shape described as ending in 2 points on each side, may soon go into extinction. Only few accessions had each of these features. There is urgent need to adopt appropriate measures to conserve these endangered qualitative features, because of the importance of variation in crop improvement programmes. Further, the grouping pattern clustered the accessions into five groups based on similarities on morphological characters and not on their geographical origin.

\section{REFERENCES}

Abu, H.B. and Buah, S.S.J. (2011). Characterization of Bambara groundnut landraces and their evaluation by farmers in the upper West Region of Ghana. Journal of Developments in Sustainable Agriculture, 6, 64-74.

Adebisi, M.A., Ariyo, J.O. and. Kehinde, B.O (2001). Variation and correlation in quantitative characteristics in Soybean, In: The proceedings of the $35^{\text {th }}$ Annual Conference of Agricultural Society of Nigeria held at University of Agricultural Abeokuta, pp. 121-125.

Afolayan, G.O., Aladele, S.E., Danquah E.U. and Bley, E. (2014). Marker assisted selection: A potent tool for sorghum improvement. $38^{\text {th }}$ Annual Conference of Genetics Society of Nigeria, Oct 2014, Edo, Benin State, pp. 193-196.

Aliero, A.A. and Morakinyo, J.A. (2001). Characterization of Digitaria exilis (Keppa). Stapf and D. iburua Stapf accessions. Nigerian Journal of Genetics, 16, 10-21. https://doi. org/10.4314/njg.v16i1.42277

Ariyo, O.J and Oduaja, A (1991). Numerical analysis variation among accession of Okra (Abelimoschus esculentus (L.) Moench, Malvacea. Annals of Botany, 16, 527-531. https:// doi.org/10.1093/oxfordjournals.aob.a088194

Bekele, F.L., and Bekele, I. (1996). A sampling of the phenetic diversity in the International Cocoa Genebank of Trinidad. Crop Science, 36, 57-64. https://doi.org/10.2135/cropsci199 6.0011183X003600010010x

Bekele, F.L., Bekele, I., Butler, D.R., and Bidaisee, G.G. (2006). Patterns of morphological variation in a sample of cacao (Theobroma cacao L.) germplasm from the International Cocoa Genebank, Trinidad. Genetic Resource and Crop Evolution, 53, 933-948. https://doi.org/10.1007/s10722004-6692-x

Caradus, J.R. and Forde, M.B. (1996). Characterisation of white clover populations collected from the Caucasus and high altitude regions of eastern Turkey. Genetic Resources and Crop Evolution, 43, 143-155. https://doi.org/10.1007/ BF00126758

Doku, E.V. (1995). Ghana In: Heller, J. Begemann, F., and Mushonga, J. (Eds.), pp 11-18. Bambara Groundnut (Vigna subterranea (L.) Verdc.). Promoting the Conservation and Use of underutilised and Neglected Crops. 9. Proceeding of Workshop on Conservation and Improvement of Bambara Groundnuts (Vigna subterranea (L.) Verdc.), 14-16 November 1995, Harare, Zimbabwe

Doku, E.V. and S.K. Karikari. (1971). The role of ants in pollination and pod production of Bambara groundnut. Economic Botany, 25(4), 357-362. https://doi.org/10.1007/ BF02985201

El eSAWI, M.,Bourke, P., Germaine, K.,Malone, R., (20120. Assessment of Morphological variation in Irish Brassica oleracea species. Journal of Agricultural Science, 4(10), 20-34. https://doi.org/10.5539/jas.v4n10p20

Engels, J.M.M., Bartley, B.G.D., and Enriquez, G.A. (1980). Cacao descriptors, their stage and modus operandi. Turrialba, 30, 209-218.

Engels, J.M.M. and Visser, L (2003) A guide to effective management of germplasm collections. IPGRI Handbook for Genebanks No. 6. Rome: International Plant Genetic Resources Institute.

Goli, A.E., Begemann, F., and Ng, N.Q. (1995) Characterization of IITA's Bambara groundnut collection. In: Proceedings of the workshop, conservation and improvement of Bambara groundnut (Vigna subterranea (L.) Verdc.) 14-16 November, 1995, Harare Zimbabwe.

Hahn, S.K. (1997). Sweet potato. In: Ecophysiology of Tropical Crops, eds Alvim, R.T. and T.T. Kozlowski, Academic Press New York, pp 237-248. https://doi.org/10.1016/B978-0-12055650-2.50013-7

IPGR, IITA, BAMNET (2000). Descriptors for Bambara groundnut (Vigna subterranea). International Plant Genetic Resources Institute, Rome, Italy; International Institute of Tropical Agriculture, Ibadan, Nigeria; The International Bambara Groundnut Network, Germany. ISBN 92-9043461-9.

Iwaro, A.D., Bekele, F.L., and Butler, D.R. (2003). Evaluation and utilisation of cacao (Theobroma cacao L.) germplasm at the International Cocoa Genebank, Trinidad. Euphytica, 130, 207-221. https://doi.org/10.1023/A:1022855131534

Kok, P.D., Robetese, J.P. and. Vanwick, E.N. (1989). Systematic study of Digitaria section Digitaria (Poaceae) in South Africa. South Africa Journal of Biotechnology, 55(2), 141-153. https://doi.org/10.1016/S0254-6299(16)31198-X

Massawe, F, J., Mwale, S.S; Azam-Ali, S.N. and Roberts, J.A. (2005). Breeding in Bambere groundnut (Vigna subterranean (L.) Verdc): strategic considerations. African Journal of Biotechnology, 4(6), 177-179.

Maharaj, K., Maharaj, P., Bekele, F.L., Ramnath, D., Bidaisee, G.G., Bekele, I., Persad, C., Jennings, K., and Sankar, R. (2011). Trinidad selected hybrids: an investigation of the phenotypic and agro-economic traits of 20 selected cacao cultivars. Tropical Agriculture (Trinidad), 88, 175-185.

Mohammed, S. M. (2014). Pre-breeding of Bambara Groundnut 
(Vigna subterranea [L.] Verdc.), PhD thesis, University of KwaZulu-Natal, Pietermaritzburg Campus, South Africa.

Ntundu, W.H., Bach, I.C., Christiansen, J.L. and Andersen, S.B. (2004). Analysis of genetic diversity in Bambara groundnut (Vigna subterranea [L.] Verdc.) landraces using amplified fragment length polymorphism (AFLP) markers. African Journal of Biotechnology, 3, 220-225.

Ntundu, W.H., Shillah, S.A., Marandu, W.Y.F., and Christiansen, J.L. (2006) Morphological diversity of bambara groundnut (Vigna subterranea (L.) Verdc.) landraces in Tanzania. Genetic Resources and Crop Evolution, 53, 367-378. https:// doi.org/10.1007/s10722-004-0580-2

Padulosi S, Hodgkin T, Williams J.T., Haq N. (2002). Underutilized crops: trends, challenges and opportunities in the $21 \mathrm{st}$
Century. In: JMM Engels, VR Rao, AHD Brown, MT Jackson (eds.) Managing plant genetic diversity. Wallingford, UK: CAB International Publishing; Rome: International Plant Genetic Resources Institute (IPGRI), pp 323-338. https://doi.org/10.1079/9780851995229.0323

Santos, R.C., Pires J.L., and Correa, R, X. (2012). Morphological characterization of leaf, flower, fruit and seed traits among Brazilian Theobroma L. species. Genetic Resources and Crop Evolution, 59, 327-345. https://doi.org/10.1007/s10722011-9685-6

William, J. G., Kubelik, A.R., Livak, K.J., Rafalski, J. A. and Tingey, S.V. (1990). DNA polymorphism amplified by arbitrary primers are useful as genetic markers. Nucleic Acid Research, 18, 6531-6535. https://doi.org/10.1093/nar/18.22.6531 